\title{
Diquat associated with copper sources for algae control: Efficacy and ecotoxicology
}

\section{Nathalia Garlich, Claudinei Da Cruz, Adilson F. Da Silva, Silvia P. Carraschi,} Igor C. Malaspina, Robinson A. Pitelli \& Silvano Bianco

To cite this article: Nathalia Garlich, Claudinei Da Cruz, Adilson F. Da Silva, Silvia P. Carraschi, Igor C. Malaspina, Robinson A. Pitelli \& Silvano Bianco (2016) Diquat associated with copper sources for algae control: Efficacy and ecotoxicology, Journal of Environmental Science and Health, Part B, 51:4, 215-221, DOI: 10.1080/03601234.2015.1120611

To link to this article: https://doi.org/10.1080/03601234.2015.1120611

册Published online: 14 Jan 2016.

Submit your article to this journal $\pi$

Џ Article views: 125

View Crossmark data ¿

Citing articles: 5 View citing articles $\longleftarrow$ 


\title{
Diquat associated with copper sources for algae control: Efficacy and ecotoxicology
}

\author{
Nathalia Garlich ${ }^{a}$, Claudinei Da Cruz ${ }^{b}$, Adilson F. Da Silva ${ }^{a}$, Silvia P. Carraschi ${ }^{c}$, Igor C. Malaspina ${ }^{a}$, Robinson A. Pitelli ${ }^{\text {, }}$, and \\ Silvano Bianco ${ }^{\mathrm{e}}$ \\ ${ }^{\mathrm{a} C o l l e g e ~ o f ~ A g r i c u l t u r a l ~ a n d ~ V e t e r i n a r y ~ S c i e n c e, ~ S a ̃ o ~ P a u l o ~ S t a t e ~ U n i v e r s i t y, ~ J a b o t i c a b a l, ~ S a ̃ o ~ P a u l o, ~ B r a z i l ; ~}{ }^{\mathrm{b}}$ University Center of the Barretos Educational \\ Foundation, Barretos, São Paulo, Brazil; ' Fisheries Institute of São Paulo, São Paulo, Brazil; 'Weed Science Environmental Research Studies, Center of the

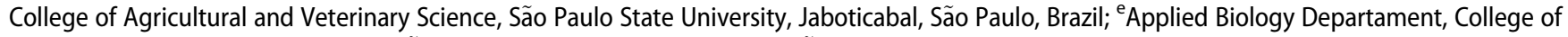 \\ Agricultural and Veterinary Science, São Paulo State University, Jabotical, São Paulo, Brazil
}

\begin{abstract}
ABSTARCT
The aims of this research were to evaluate the efficacy of copper oxychloride $\left(\mathrm{CuCl}_{2} \cdot 3 \mathrm{Cu}(\mathrm{OH})_{2}\right)$, copper hydroxide $\left(\mathrm{Cu}(\mathrm{OH})_{2}\right)$ and diquat (1.1'-ethylene-2.2'-bipyridyldiylium dibromide), isolated and in association with $0.1 \%$ of both copper sources, in the control of the unicellular algae Ankistrodesmus gracilis and the filamentous algae Pithophora kewesis, and to determine the acute toxicity of the tested chemicals in Hyphressobrycon eques, Pomacea canaliculata, Lemna minor and Azolla caroliniana. The efficacy was estimated by the methods of chlorophyll $a$ and pheophytin $a$ readings, changed into growth inhibition percentage. Both algae were exposed to the following concentrations: $0.2 ; 0.4 ; 0.8 ; 1.2 \mathrm{mg} \mathrm{L}^{-1}$ of diquat and its association with the copper sources; and $0.1 ; 0.3 ; 0.5 ; 0.7 ; 1.0$ and $1.5 \mathrm{mg} \mathrm{L}^{-1}$ in the isolated applications of copper hydroxide and copper oxychloride. An untreated control was kept. The acute toxicity was estimatedby $50 \%$ lethal concentration (LC50). The copper sources were effective for $A$. gracilis control, at rates as high as $0.1 \mathrm{mg} \mathrm{L}^{-1}$ (>95\% efficacy). Isolated diquat and its association with copper hydroxide were both effective at rates as high as $0.4 \mathrm{mg} \mathrm{L}^{-1}$, with 95 and $88 \%$ control efficacy, respectively. The copper oxychloride was effective at $0.2 \mathrm{mg} \mathrm{L}^{-1}$, with $93 \%$ efficacy. None of the tested chemicals and associations was effective on $P$. kewesis control. The most sensitive non target organism to the tested chemicals was $L$. minor; the less sensitive was $H$. eques.
\end{abstract}

\section{ARTICLE HISTORY}

Received 30 July 2015

\section{KEYWORDS}

Algaecide; chemical substances; environmental assessment; secondary effect

\section{Introduction}

The anthropic activity promotes the increase in nitrogen and phosphorous content in the aquatic environment, which leads to eutrophication and biomass increase of the primary producers. ${ }^{[1]}$

The algae growth promotes an ecological imbalance in the food chain and decreases the dissolved oxygen in the water; in this context, the mortality of aquatic aerobic organisms may occur. Besides, it causes the degradation of the water quality, changes the portability, increases the treatment price, causes damages to the public water supply and hinders its use for recreation. ${ }^{[2]}$

The use of chemical substances is a viable alternative for macrophyte ${ }^{[3]}$ and algae control, ${ }^{[4]}$ due to practicality, faster results, adequate efficacy and low toxicity for the non target organisms. Peterson et al. ${ }^{[5]}$ observed good efficacy for hexazinone and diquat in the growth reduction of unicellular algae and cyanobacteria. Other authors also tested diuron and oxyfluorfen in Scenedesmus obliquus control; ${ }^{[6]}$ and paraquat in the inhibition of Scenedesmus acutus, Selenastrum capricornutum and Chlorella vulgaris. ${ }^{[7]}$ Some herbicides may present secondary effects in algae development; however, further research is required to elucidate this hypothesis, due to the lack of data in this regard.

Different copper sources associated to an herbicide may be an alternative for algae control in the aquatic environment.
Copper may be an effective tool for algae control once it inhibited cell division and photosynthesis of Chlorella pyrenoidosa, S. obliquus ${ }^{[8]}$ and Pseudokirchneriella subcapitata. ${ }^{[9]}$

According to Einicker-Lamas et al., ${ }^{[10]}$ copper causes mitochondrial alterations, disorganization and alterations in the composition of proteins and lipids from the chloroplast in Euglena gracilis. According to Rodrigues et al. ${ }^{[11]}$ and OliveiraFilho et al., ${ }^{[4]}$ the copper sulfate, copper oxychloride $\left(\mathrm{CuCl}_{2} \cdot 3 \mathrm{Cu}(\mathrm{OH})_{2}\right.$ and copper oxide are toxic to Raphidocelis subcapitata. Copper sulfate and copper peroxide are successfully used for algae and cyanobacteria control in water bodies for public supply. ${ }^{[12]}$

The exposure to high copper concentrations, along with light exposure increase, disturbs the metabolic pathways through deleterious effects in algae structure and physiology. Consequently, the nitrogen fixation is compromised, and the absorption of mineral elements is reduced. Other effects are also observed, such as the disarrangement of the plasmatic membrane, cellular mobility decrease and organelles instability. ${ }^{[13-15]}$

The application of an herbicide associated to an algaecide may facilitate the macrophyte and algae control, since it interferes in the absorption of nutrients from decomposition, thus minimizing the environmental effects of algae growth. The association between diquat (1.1'-ethylene-2.2'-bipyridyldiylium

CONTACT Nathalia Garlich nathalia.garlich@gmail.com $\Theta$ College of Agricultural and Veterinary Sciences, São Paulo State University, Jaboticabal, São Paulo CEP 14884-900, Brazil.

(c) 2016 Taylor \& Francis Group, LLC 
dibromide) and copper sources is more effective in algae and macrophyte control than the individual use of the herbicide. ${ }^{[16,17]}$

However, the application of chemical products in the aquatic environment is questionable, concerning environmental safety and health. Thus, ecotoxicological studies for non-target organisms are essential for the decision-making about chemical intervention in this system. ${ }^{[18]}$

Organisms from several levels of the food chain are used in the ecotoxicological evaluation, accordingly to features such as sensitivity, management complexity, reproductive cycle duration, geographical distribution, and size. Among some of the bioindicators used in the ecotoxicological assessments are the fish, ${ }^{[19]}$ the snail ${ }^{[20]}$ and aquatic macrophytes. ${ }^{[21,22]}$

Thus, the aim of this research was to evaluate the efficacy of diquat, copper oxychloride and copper hydroxide $\left(\mathrm{Cu}(\mathrm{OH})_{2}\right)$, and the associations of the herbicide with $0.1 \%$ of copper oxychloride and $0.1 \%$ of copper hydroxide in the control of the unicellular algae Ankistrodesmus gracilis and the filamentous algae Pithophora kewesis, and to estimate the $50 \%$ acute toxicity (LC50) for Hypressobrycon eques, Pomacea canaliculata, Lemna minor and Azolla caroliniana.

\section{Material and methods}

The chemicals evaluatedin this research were the herbicide diquat $\left(200 \mathrm{~g} \mathrm{~L}^{-1}\right)$, copper oxychloride $\left(\mathrm{CuCl}_{2} \cdot 3 \mathrm{Cu}(\mathrm{OH})_{2}\right)$ $\left(588 \mathrm{~g} \mathrm{~L}^{-1}\right)$ and copper hydroxide $\left(\mathrm{Cu}(\mathrm{OH})_{2}\right)\left(690 \mathrm{~g} \mathrm{~kg}^{-1}\right)$. The efficacy evaluation in algae control was performed through chlorophyll $a(\mathrm{Chl} a)$ and Pheophytin $a$ (Pheo) readings. The chlorophyll degradation was estimated by pheophytin $a$ (Pheo) content. The gathered data was submitted to the Chla and Pheo equation, according to CETESB. ${ }^{[23]}$ The calculated data was expressed as growth inhibition percentage for Chla and degradation percentage for Pheo. The efficacy and degradation data were submitted to variance analysis (ANOVA) and the means were compared through Tukey's test, at 99\% confidence level. The acute toxicity (lethal concentration-LC50) was estimated by the Trimmed Spearman-Karber software ${ }^{[24]}$ and the chemicals were classified accordingly to the ecotoxicological classes proposed by Zucker. ${ }^{\text {[25] }}$

\section{Control efficacy for A. gracilis and P. kewesis}

Samples of both algae species were collected from mesocosms (400 L tanks) and were transferred to Erlenmeyer flasks $(2.0 \mathrm{~L})$, containing a culture medium based on the chemical fertilizer NPK (10:5:20) associated to macrophyte extract (Eicchorniacrassipes) (Sipaúba-Tavares et al.). ${ }^{[26]}$ The material was kept in biological oxygen demand chamber (BOD), at $25.0 \pm 1.0{ }^{\circ} \mathrm{C}$, with photoperiod of 12 light hours and artificial aeration, promoted by air blower.

Samples of the unicellular algae $(50 \mathrm{~mL}$ from the culture) were transferred to a test tube $(100 \mathrm{~mL})$ and were kept for 24 hours under bioassay room conditions, at $25.0 \pm 1.0^{\circ} \mathrm{C}$, $12 \mathrm{~h}$ photoperiod, at 1000 lux for acclimatization. For the filamentous algae, $1.0 \mathrm{~g}$ fresh weight was transferred to test tubes $(100 \mathrm{~mL})$, which were filled with $50 \mathrm{~mL}$ of water. The tubes were submitted to acclimatization for $24 \mathrm{~h}$, under the same conditions of the unicellular algae.

After the acclimatization period, the diquat applications were performed at the doses of $0.2 ; 0.4 ; 0.8$ and $1.2 \mathrm{mg} \mathrm{L}^{-1}$; the diquat associations with the copper sources were tested at the same rates. Both copper sources were individually tested at the following rates: $0.1 ; 0.3 ; 0.5 ; 0.7 ; 1.0$ and $1.5 \mathrm{mg} \mathrm{L}^{-1}$. An untreated control without any application was also kept. The experimental design was completely randomized, with five repetitions per treatment. The algae were exposed to the chemicals for 15 days.

At the end of the experimental period, three experimental plots from each concentration were collected and filtered with a vacuum pump in a kitassato system. $10 \mathrm{~mL}$ acetone (90\%) was added and the material was stored in a freezer at $-4.0^{\circ} \mathrm{C}$ for 24 hours, for pigments extraction. The samples were submitted to centrifugation for 20 minutes and the supernatant was transferred to spectrophotometric buckets with $2.5 \mathrm{~cm}$ optical path length for the spectrophotometer readings (OdyssayHach Company DR/2500). Acetone $90 \%$ was used as white standard for the optical path, and the measured wave lengths for Chlorophyll $a$ were 750 and $664 \mathrm{~nm}$, and for Pheophytin $a$ were 750 and $665 \mathrm{~nm}$. After the Chla readings, $0.1 \mathrm{~mL}$ hydrochloric acid 0.1 $\mathrm{M}$ was added for Pheo readings. ${ }^{[23]}$

\section{Ecotoxicological experiments for $\mathrm{H}$. eques and $\mathrm{P}$. canaliculata}

Fish and snails with $0.74 \pm 0.19 \mathrm{~g}$ and $1.37 \pm 0.21 \mathrm{~g}$ average weigh, respectively, were selected to perform the ecotoxicological assays. The individuals from both species were acclimatized for seven days, under bioassay room conditions. ${ }^{[27]}$

The bioindicators sensibility was evaluated with potassium chloride $(\mathrm{KCl})$ as reference substance. The LC50;48 $\mathrm{h}$ for the fish and snails were $1.68 \mathrm{~g} \mathrm{~L}^{-1}$ and $2.85 \mathrm{~g} \mathrm{~L}^{-1}$, respectively. Lower and upper confidence limits were $1.32-2.14 \mathrm{~g} \mathrm{~L}^{-1}$ and 2.13-3.82 $\mathrm{g} \mathrm{L}^{-1}$, respectively.

After the preliminary tests, the definitive $H$. eques tests were performed at the following concentrations: $61.27 ; 79.66 ; 103.00$ and $134.63 \mathrm{mg} \mathrm{L}^{-1}$ diquat; $3.60 ; 11.80 ; 14.80$ and $18.40 \mathrm{mg} \mathrm{L}^{-1}$ $\mathrm{CuCl}_{2} .3 \mathrm{Cu}(\mathrm{OH})_{2} ; 1.10 ; 3.60 ; 11.80 ; 14.75 ; 18.43 ; 23.00$ and $28.80 \mathrm{mg} \mathrm{L}^{-1} \mathrm{Cu}(\mathrm{OH})_{2} ; 3.40 ; 6.80 ; 13.60$ and $27.20 \mathrm{mg} \mathrm{L}^{-1}$ $\mathrm{D}+0.1 \% \mathrm{CuCl}_{2} .3 \mathrm{Cu}(\mathrm{OH})_{2} ;$ and $6.00 ; 10.50 ; 18.40 ; 32.20$; and $56.30 \mathrm{mg} \mathrm{L}^{-1} \mathrm{D}+0.1 \% \mathrm{Cu}(\mathrm{OH})_{2}$. An untreated control was kept. All treatments were performed with three repetitions and three fish per repetition.

For $P$. canaliculata definitive tests, the concentrations were as follows: $1.06 ; 3.43 ; 11.16 ; 36.26 ; 117.84 \mathrm{mg} \mathrm{L}^{-1}$ diquat; 0.11 ; $0.34 ; 1.11 ; 3.62$ and $11.86 \mathrm{mg} \mathrm{L}^{-1} \mathrm{CuCl}_{2} .3 \mathrm{Cu}(\mathrm{OH})_{2} ; 0.01 ; 0.03$; $0.11 ; 0.34 ; 1.11 ; 3.62$ and $11.80 \mathrm{mg} \mathrm{L}^{-1} \mathrm{Cu}(\mathrm{OH})_{2} ; 0.11 ; 0.34$; $1.11 ; 3.62$ and $11.80 \mathrm{mg} \mathrm{L}^{-1} \mathrm{D}+0.1 \% \mathrm{CuCl}_{2} \cdot 3 \mathrm{Cu}(\mathrm{OH})_{2}$ and $0.03 ; 0.11 ; 0.34 ; 1.11 ; 3.62$ and $11.80 \mathrm{mg} \mathrm{L}^{-1} \mathrm{D}+0.1 \% \mathrm{Cu}(\mathrm{OH})_{2}$. An untreated control was also kept. All treatments were performed with three repetitions, with five animals per repetition.

The experiments were performed in a static system for 48 hours. The assessments of fish mortality, snail mobility and the water quality variables (temperature, dissolved oxygen, electrical conductivity and $\mathrm{pH}$ ) were evaluated at 0,24 and 48 hours after exposure. 


\section{Ecotoxicological experiments with L. minor and A. caroliniana}

The macrophytes L. minor and A. caroliniana were acclimatized under bioassay room conditions, with $25.0 \pm 2.0^{\circ} \mathrm{C}$ and constant illumination (1000 lux) for 3 days. After the acclimatization, four L. minor individuals with three fronds each (12 total fronds) and five A. caroliniana individuals were selected. The macrophyte were distributed in $100 \mathrm{~mL}$ glass containers, containing $50 \mathrm{~mL}$ culture medium (Hoagland's), and were acclimatized for another $24 \mathrm{~h}$. After this period, $50 \mathrm{~mL}$ Hoagland's containing the tested dilutions was added.

The plants sensibility was assessed with sodium chloride $(\mathrm{NaCl})$ as reference substance. The LC50;7 $\mathrm{d}$ for L. minor and A. caroliniana were $0.65 \mathrm{~g} \mathrm{~L}^{-1}$ and $2.14 \mathrm{~g} \mathrm{~L}^{-1}$, respectively. The lower and upper confidence limits were $0.62-0.69 \mathrm{~g} \mathrm{~L}^{-1}$ and $1.97-2.31 \mathrm{~g} \mathrm{~L}^{-1}$, respectively.

For the L. minor definitive tests, the following concentrations were added: $0.001 ; 0.0050 ; 0.01 ; 0.05 \mathrm{mg} \mathrm{L}^{-1}$ diquat; $0.001 ; 0.01 ; 0.05$ and $0.1 \mathrm{mg} \mathrm{L}^{-1} \mathrm{Cu}(\mathrm{OH})_{2} ; 0.001 ; 0.005 ; 0.01$; $0.05 ; 0.1$ and $1.0 \mathrm{mg} \mathrm{L}^{-1} \mathrm{CuCl}_{2} .3 \mathrm{Cu}(\mathrm{OH})_{2}$ and $0.001 ; 0.0025$; $0.0050 ; 0.0075$ and $0.01 \mathrm{mg} \mathrm{L}^{-1} \mathrm{D}+0.1 \% \mathrm{CuCl}_{2} .3 \mathrm{Cu}(\mathrm{OH})_{2}$ and $\mathrm{D}+0.1 \% \mathrm{Cu}(\mathrm{OH})_{2}$.

The concentrations added in the definitive tests for A. caroliniana were as follows: $0.005 ; 0.01 ; 0.022 ; 0.05 ; 0.11$ and $0.25 \mathrm{mg}$ $\mathrm{L}^{-1}$ diquat; $0.10 ; 0.32 ; 1.06 ; 3.43 ; 11.15 ; 36.26$ and $118.00 \mathrm{mg} \mathrm{L}^{-1}$ $\mathrm{CuCl}_{2} .3 \mathrm{Cu}(\mathrm{OH})_{2} ; 0.10 ; 1.00 ; 3.50 ; 11.20 ; 36.50$ and $118.00 \mathrm{mg}$ $\mathrm{L}^{-1} \mathrm{Cu}(\mathrm{OH})_{2} ; 0.01 ; 0.05 ; 0.1 ; 0.5$ and $1.0 \mathrm{mg} \mathrm{L}^{-1} \mathrm{D}+0.1 \% \mathrm{Cu}$ $(\mathrm{OH})_{2} ;$ and $0.005 ; 0.01 ; 0.16 ; 0.24$ and $0.38 \mathrm{mg} \mathrm{L}^{-1}$ $\mathrm{D}+0.1 \% \mathrm{CuCl}_{2} .3 \mathrm{Cu}(\mathrm{OH})_{2}$. In both definitive tests, three repetitions for each treatment and an untreated control were kept.

The plants mortality was evaluated at the third, fifth and seventh day of exposure. L. minor was evaluated accordingly to alterationsin growth rate, necrosis and frond chlorosis. ${ }^{[28]}$ For A. caroliniana, the evaluations were performed through a rank scale (E to A), according to Silva et al. ${ }^{[22]}$

\section{Results and discussion}

\section{Control efficacy for the unicellular algae Ankistrodesmus gracilis}

Copper oxychloride decreased significantly the chlorophyll $a$ (Chla) content in all tested concentrations. The highest Chla reduction occurred at $1.0 \mathrm{mg} \mathrm{L}^{-1}$, corresponding to $0.09 \mu \mathrm{g}$
$\mathrm{L}^{-1}$ Chla. In comparison with $2.90 \mu \mathrm{g} \mathrm{L}^{-1} \mathrm{Chl} a$ in the untreated control, the efficacy has corresponded to $97 \%$. According to Pheo readings, thehighest degradation occurred at $0.1 \mathrm{mg} \mathrm{L}^{-1}\left(0.63 \mu \mathrm{g} \mathrm{L}^{-1}\right.$ Pheo), corresponding to $18 \%$ efficacy in comparison with the untreated control $\left(3.44 \mu \mathrm{g} \mathrm{L}^{-1}\right.$ Pheo) (Fig. 1).

Copper hydroxide decreased significantly the Chla content in all tested concentrations. The highest reduction occurred at $0.3 \mathrm{mg} \mathrm{L}^{-1}\left(0.14 \mu \mathrm{g} \mathrm{L}^{-1} \mathrm{Chl}\right.$ ), corresponding to $96 \%$ efficacy, in comparison with the untreated control $\left(2.90 \mu \mathrm{g} \mathrm{L}^{-1} \mathrm{Chla}\right)$. According to the Pheo readings, the highest degradation occurred at $1.5 \mathrm{mg} \mathrm{L}^{-1}$ (1.12 $\mu \mathrm{g} \mathrm{L}^{-1}$ Pheo), corresponding to $32 \%$ efficacy in comparison with the untreated control $(3.44 \mu \mathrm{g}$ $\mathrm{L}^{-1}$ Pheo) (Fig. 1).

The tested concentrations above $0.1 \mathrm{mg} \mathrm{L}^{-1}$ of both copper sources were effective for $A$. gracilis control, as well as observed for copper sulfate in $R$. subcapitata (IC50;96 $\mathrm{h}=0.15$ and $\left.0.14 \mathrm{mg} \mathrm{L}^{-1}\right) \cdot{ }^{[11-14]}$ However, higher concentrations of the copper sources were required in the present research to promote the same effect observed by Oliveira-Filho et al ${ }^{[4]}$ in $R$. subcapitata (IC50;96 $\mathrm{h}=0.073$ and $0.071 \mathrm{mg} \mathrm{L}^{-1}$ ). Through the chlorophyll readings method, Wong and Chang ${ }^{[29]}$ observed that 0.5 and $0.75 \mathrm{mg} \mathrm{L}^{-1}$ of copper were $100 \%$ effective in $C$. pyrenoidosa.

Copper is an essential micronutrient in algae metabolism, and performs important functions in the electrons transport in several enzymatic systems, such as oxidase, amine oxidase and cytochrome c. ${ }^{[15]}$ However, copper exposure may inhibit photosynthesis, once the photosynthetic apparatus is sensitive to high concentrations of the ion. It may also affect the chloroplast structure, by decreasing the electron transport rate and the lipids biosynthesis, affecting the photosynthetic efficiency as a consequence. ${ }^{[30,31]}$

The herbicide diquat caused significant decrease in Chla content at $0.4 ; 0.8$ and $1.2 \mathrm{mg} \mathrm{L}^{-1}$. The highest reduction occurred at $0.8 \mathrm{mg} \mathrm{L}^{-1}\left(0.13 \mu \mathrm{g} \mathrm{L}^{-1} \mathrm{Chl} a\right)$, corresponding to $95 \%$ efficacy, in comparison with the untreated control (3.57 $\mu \mathrm{g} \mathrm{L}^{-1} \mathrm{Chl} a$ ). The highest degradation occurred at $0.2 \mathrm{mg}$ $\mathrm{L}^{-1}$ (4.59 $\mu \mathrm{g} \mathrm{L}^{-1}$ Pheo), with $03 \%$ Pheo increase, in comparison with the untreated control (4.45 $\mu \mathrm{g} \mathrm{L}^{-1}$ Pheo) (Fig. 2).

The association $\mathrm{D}+0.1 \% \mathrm{CuCl}_{2} \cdot 3 \mathrm{Cu}(\mathrm{OH})_{2}$ caused significant decrease in Chla content for all tested concentrations. The highest reduction occurred at $1.2 \mathrm{mg} \mathrm{L}^{-1}(0.26 \mu \mathrm{g} \mathrm{L}-1 \mathrm{Chl} a)$, corresponding to $93 \%$ efficacy in comparison with the

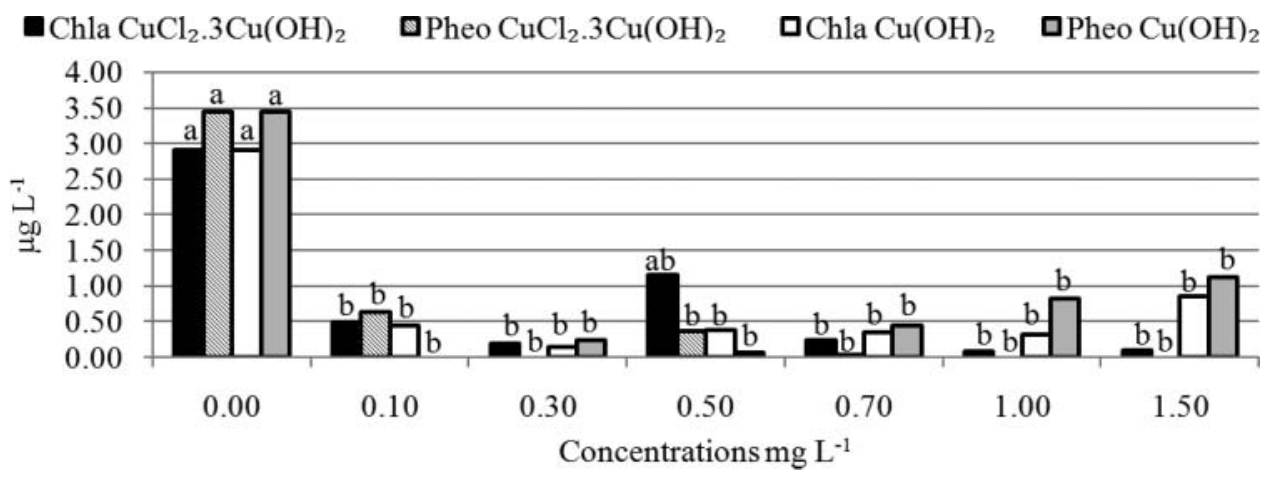

Figure 1. Chlorophyll a (Chla) and Pheophytin a (Pheo) mean values for unicellular algae $A$. gracilis after 15 days of exposure to copper oxychloride $\left(\mathrm{CuCl} 2_{2} .3 \mathrm{Cu}(\mathrm{OH})_{2}\right)$ and copper hydroxide $\left(\mathrm{Cu}(\mathrm{OH})_{2}\right)$. Means with the same letter do not differ significantly from each other (Tukey, $P<0.01$ ). 


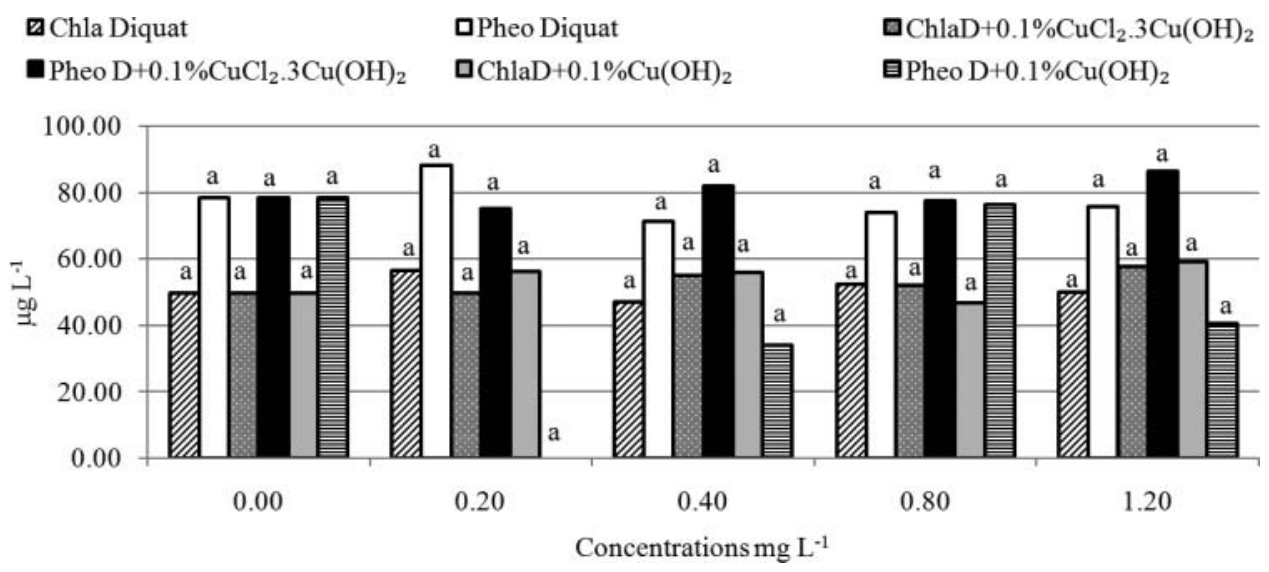

Figure 2. Mean values for Chlorophyll $a$ (Chla) and Pheophytin $a$ (Pheo) from unicellular algae $A$. gracilis after 15 days of exposure to Diquat, Diquat in association with Copper oxychloride $\left(\mathrm{D}+0.1 \% \mathrm{CuCl}_{2} .3 \mathrm{Cu}(\mathrm{OH})_{2}\right)$ and copper hydroxide $\left(\mathrm{D}+0.1 \% \mathrm{Cu}(\mathrm{OH})_{2}\right)$. Means with the same letter do not differ significantly from each other $(\mathrm{Tukey}, P$ $<0.01)$.

untreated control (3.57 $\left.\mu \mathrm{g} \mathrm{L}^{-1} \mathrm{Chl} a\right)$. The highest degradation occurred at $0.2 \mathrm{mg} \mathrm{L}^{-1}\left(2.59 \mu \mathrm{g} \mathrm{L}^{-1}\right.$ Pheo), corresponding to $58 \%$ efficacy in comparison with the untreated control $(4.45 \mu \mathrm{g}$ $\left.\mathrm{L}^{-1} \mathrm{Pheo}\right)$.

The association $\mathrm{D}+0.1 \% \mathrm{Cu}(\mathrm{OH})_{2}$ promoted significant Chl $a$ decrease at $0.4 ; 0.8$ and $1.2 \mathrm{mg} \mathrm{L}^{-1}$. The highest reduction occurred at $0.8 \mathrm{mg} \mathrm{L}^{-1}\left(0.32 \mu \mathrm{g} \mathrm{L}^{-1} \mathrm{Chl} a\right)$, corresponding to $92 \%$ efficacy in comparison with the untreated control $(3.57 \mu \mathrm{g}$ $\left.\mathrm{L}^{-1} \mathrm{Chla}\right)$. The highest degradation occurred at $0.2 \mathrm{mg} \mathrm{L}^{-1}$ (4.28 $\mu \mathrm{g} \mathrm{L}^{-1} \mathrm{Pheo}$ ), corresponding to $96 \%$ efficacy in comparison with the untreated control (4.45 $\mu \mathrm{g} \mathrm{L}^{-1}$ Pheo) (Fig. 2).

The most effective concentrations for $A$. gracilis control were the following: diquat at $0.8 \mathrm{mg} \mathrm{L}^{-1} ; \mathrm{D}+0.1 \% \mathrm{Cu}(\mathrm{OH})_{2}$ and $\mathrm{D}+0.1 \% \mathrm{CuCl}_{2} .3 \mathrm{Cu}(\mathrm{OH})_{2}$ at $0.4 ; 0.8$ and $1.2 \mathrm{mg} \mathrm{L}^{-1}$. The diquat concentration which presented A. gracilis control in this research was higher than observed in S. capricornutum control $\left(\mathrm{EC} 50 ; 96 \mathrm{~h}=0.08 \mathrm{mg} \mathrm{L}^{-1}\right){ }^{[32]}$ The diquat effective dose was also higher than the paraquat effective dose in the control of $C$. vulgaris $\left(\mathrm{EC} 50=0.0002 \mathrm{mg} \mathrm{L}^{-1}\right)$ and $R$. subcapitata $(\mathrm{EC} 50=$ $\left.0.018 \mathrm{mg} \mathrm{L}^{-1}\right) \cdot{ }^{[33,34]}$ Paraquat also caused growth inhibition with $96 \mathrm{~h}$ exposure, at concentrations as high as $0.05 \mathrm{mg} \mathrm{L}^{-1}$ in C. vulgaris, Scenedesmus quadricauda and S. acutus. ${ }^{[7]}$

Diquat is recommended for submersed and floating macrophyte control in lakes, ponds and irrigation canals in North America, Europe, Australia and Japan, at concentrations as low as $1.0 \mathrm{mg} \mathrm{L}^{-1}$. The molecule presents photochemical degradation, and its half life in the aquatic environment is lower than $48 \mathrm{~h}$. The controlled macrophyte releases the absorbed herbicide during decomposition, which links to colloidal particles in the water. Thus, part of the released herbicide is removed from the aquatic environment, decreasing substantially the herbicide's residue. ${ }^{[35]}$ Thus, along with the herbicidal activity, it can also be considered an algaecide agent. The tested concentrations are within the registry interval and may obtain significant results in macrophyte and algae growth reduction, due to its effect on decreasing the lipids peroxidation.

\section{Control efficacy for the filamentous algae P. kewesis}

None of the copper sources was effective in P. kewesis control. The highest Chla reduction promoted by $\mathrm{CuCl}_{2} \cdot 3 \mathrm{Cu}(\mathrm{OH})_{2}$ application has occurred at $0.7 \mathrm{mg} \mathrm{L}^{-1}\left(39.06 \mu \mathrm{g} \mathrm{L}^{-1} \mathrm{Chl} a\right)$, with $22 \%$ efficacy in comparison with the untreated control (49.69 $\mu \mathrm{g} \mathrm{L}^{-1} \mathrm{Chl}$ ). Accordingly to Pheo content, the highest degradation occurred at $0.1 \mathrm{mg} \mathrm{L}^{-1}\left(94.59 \mu \mathrm{g} \mathrm{L}^{-1}\right)$, corresponding to $20 \%$ Pheo increase in comparison with the untreated control $\left(78.30 \mu \mathrm{g} \mathrm{L}^{-1}\right)$ (Fig. 3).

$\mathrm{The} \mathrm{Cu}(\mathrm{OH})_{2}$ application presented the highest Chla reduction at $1.0 \mathrm{mg} \mathrm{L}^{-1}$ (38.53 $\mu \mathrm{g} \mathrm{L}^{-1} \mathrm{Chl}$ ) ), corresponding to $23 \%$ efficacy in comparison with the untreated control $(49.69 \mu \mathrm{g}$

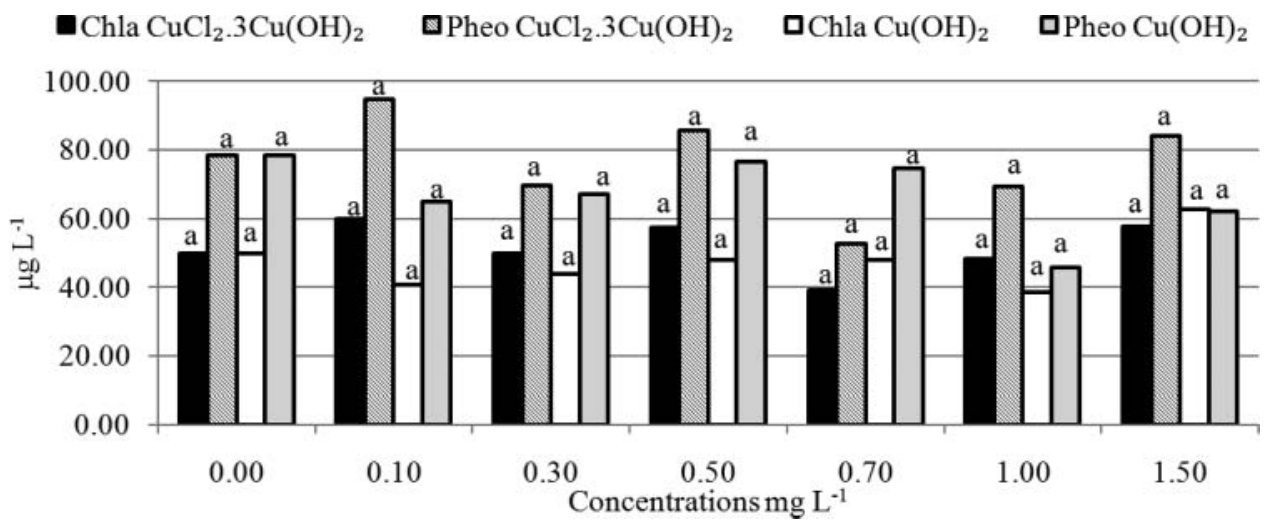

Figure 3. Mean values of Chlorophyll $a(\mathrm{Chl} a)$ and Pheophytin $a$ (Pheo) from filamentous algae $\mathrm{P}$. kewesis, after 15 days of exposure to copper oxychloride (CuCl $2.3 \mathrm{Cu}$ $\left.(\mathrm{OH})_{2}\right)$ and copper hydroxide $\left(\mathrm{Cu}(\mathrm{OH})_{2}\right)$. Means with the same letter weren't statistically significant (Tukey, $P<0.01$ ). 

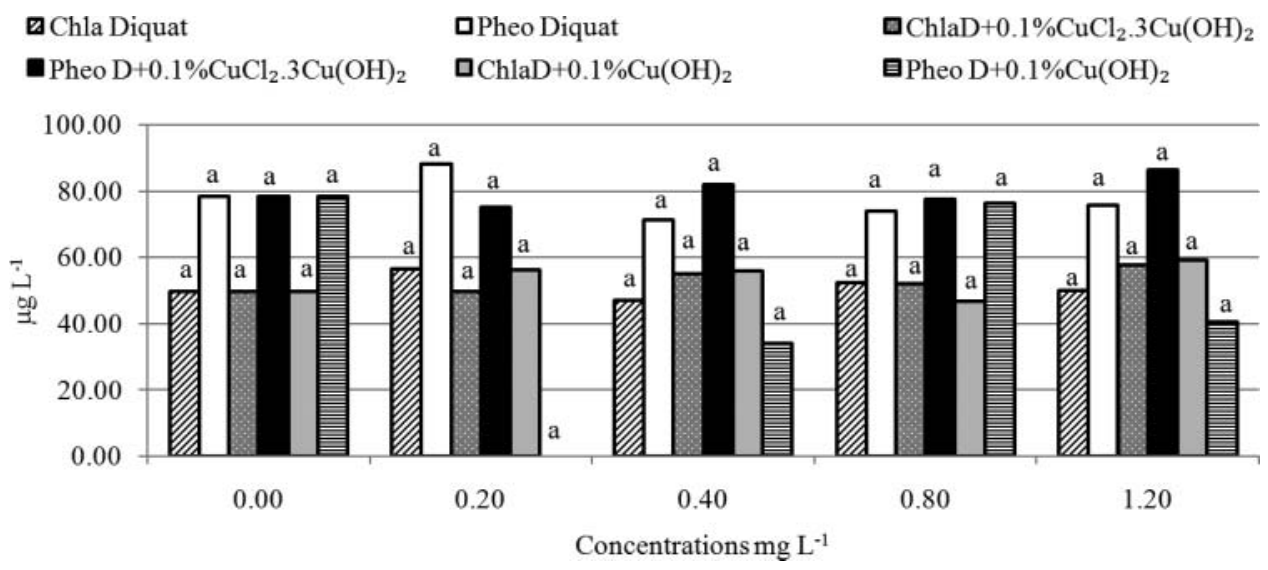

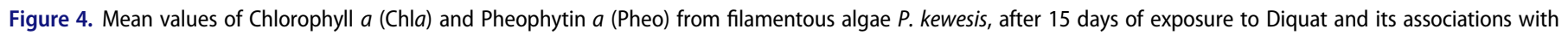
copper oxychloride $\left(\mathrm{D}+0.1 \% \mathrm{CuCl}_{2} \cdot 3 \mathrm{Cu}(\mathrm{OH})_{2}\right)$ and copper hydroxide $\left(\mathrm{D}+0.1 \% \mathrm{Cu}(\mathrm{OH})_{2}\right)$. Means with the same letter weren't statistically significant $(\mathrm{Tukey}, P<0.01)$.

$\mathrm{L}^{-1} \mathrm{Chl} a$ ). Accordingly to Pheo content, the highest degradation occurred at $0.5 \mathrm{mg} \mathrm{L}^{-1}\left(76.36 \mu \mathrm{g} \mathrm{L}^{-1}\right)$, corresponding to 97\% efficacy in comparison with the untreated control (78.30 $\mu \mathrm{g} \mathrm{L}^{-1}$ Pheo) (Fig. 3).

In the test with diquat and the associations $\mathrm{D}+0.1 \% \mathrm{CuCl}_{2} .3 \mathrm{Cu}(\mathrm{OH})_{2}$ and $\mathrm{D}+0.1 \% \mathrm{Cu}(\mathrm{OH})_{2}$, no significant control in $P$. kewesis was observed. Diquat promoted the highest reduction at $0.4 \mathrm{mg} \mathrm{L}^{-1}\left(46.99 \mu \mathrm{g} \mathrm{L}^{-1}\right)$, corresponding to $6 \%$ efficacy in comparison with the untreated control $(49.69 \mu \mathrm{g}$ $\left.\mathrm{L}^{-1}\right)$. Accordingly to Pheo content, the highest degradation occurred at $0.2 \mathrm{mg} \mathrm{L}^{-1}\left(88.26 \mu \mathrm{g} \mathrm{L}^{-1}\right)$, corresponding to $12 \%$ Pheo increase in comparison with the untreated control (78.30 $\mu \mathrm{g} \mathrm{L}^{-1}$ ) (Fig. 4).

No reduction in Chla content was observe in the test with the association $\mathrm{D}+0.1 \% \mathrm{CuCl}_{2} .3 \mathrm{Cu}(\mathrm{OH})_{2}$. Accordingly to the Pheo content, the highest degradation occurred at $1.2 \mathrm{mg} \mathrm{L}^{-1}$ (86.41 $\mu \mathrm{g} \mathrm{L}^{-1}$ Pheo), corresponding to $10 \%$ Pheo increase in comparison with the untreated control (78.3 $\left.\mu \mathrm{g} \mathrm{L}^{-1}\right)$ (Fig. 4).

The higher Chla reduction promoted by the association $\mathrm{D}+0.1 \% \mathrm{Cu}(\mathrm{OH})_{2}$ occurred at $0.8 \mathrm{mg} \mathrm{L}^{-1}\left(46.88 \mu \mathrm{g} \mathrm{L}^{-1}\right)$, corresponding to $6 \%$ efficacy in comparison with the untreated control $\left(49.69 \mu \mathrm{g} \mathrm{L}^{-1}\right)$. Accordingly to Pheo, the highest degradation occurred at $0.8 \mathrm{mg} \mathrm{L}^{-1}$, corresponding to $97 \%$ efficacyin comparison with the untreated control (Fig. 4).

The low efficacy in $P$. kewesis control was also reported by other authors, regarding specifically copper sulfate. ${ }^{[16]}$ However, other authors also described that diquat was effective on filamentous algae control, ${ }^{[36]}$ differing from the present research.

\section{Ecotoxicity experiments for $H$. eques, $P$. canaliculata, $L$. minor and A. caroliniana}

The most sensitive organism to diquat was L. minor (LC50;7 d $=0.01 \mathrm{mg} \mathrm{L}{ }^{-1}$; confidence limits: $0.0-0.01 \mathrm{mg} \mathrm{L}^{-1}$ ), and the less sensitive organism was $H$. eques (LC50;48 $\mathrm{h}=103.61 \mathrm{mg}$ $\left.\mathrm{L}^{-1} ; 89.71-119.66 \mathrm{mg} \mathrm{L}^{-1}\right)$. The sensitivity sequence of the bioindicator organisms to diquat was L. minor $>$ A. caroliniana $>$ P. canaliculata $>$ H. eques (Table 1 ).

The diquat's acute toxicity to L. minor was similar to presented by Fairchild et al. ${ }^{[32]}\left(\right.$ EC50;96 $\left.\mathrm{h}=0.018 \mathrm{mg} \mathrm{L}^{-1}\right)$.
According to the same authors, the $50 \%$ effective concentration for paraquat was $0.051 \mathrm{mg} \mathrm{L}^{-1}$. The slightly difference between these concentrations indicates that this herbicide group is toxic to the present macrophyte.

Diquat was more toxic to A. caroliniana than other herbicides, such as 2,4-D (LC50;7 d $\left.=708.35 \mathrm{mg} \mathrm{L}^{-1}\right)$, clomazone (LC50;7 $\mathrm{d}=129.63 \mathrm{mg} \mathrm{L}^{-1}$ ), oxyfluorfen (LC50;7 $\mathrm{d}=$ $80.50 \mathrm{mg} \mathrm{L}^{-1}$ ), glyphosate as Trop ${ }^{\otimes}$ formulation (LC50;7 $\mathrm{d}=$ $38.91 \mathrm{mg} \mathrm{L}^{-1}$ ) and glyphosate as Scout $^{\oplus}$ formulation (LC50;7 d $\left.=23.66 \mathrm{mg} \mathrm{L}^{-1}\right) \cdot{ }^{[22]}$ However, diquat was less toxic to $P$. canaliculata than the paraquat (both herbicides from the same chemical group) to Pomacea lineata, with LC50;96 h $=0.35 \mathrm{mg} \mathrm{L}^{-1} \cdot{ }^{[37]}$ Diquat was less toxic to H. eques than to

Table 1. Chemicals acute toxicity $\left(\mathrm{mg} \mathrm{L}^{-1}\right)$ to nontarget organisms.

\begin{tabular}{|c|c|c|c|c|}
\hline Bioindicators & L.L. ${ }^{*}$ & $\mathrm{LC} / 50^{* * *}\left(\mathrm{mg} \mathrm{L}^{-1}\right)$ & U.L.* & Zucker $^{[25]}$ \\
\hline \multicolumn{5}{|l|}{ Diquat } \\
\hline H. eques & 89.71 & 103.61 & 119.66 & Practically non-toxic \\
\hline P. canaliculata & 2.50 & 4.71 & 8.88 & Moderately toxic \\
\hline L. minor & 0.00 & 0.01 & 0.01 & Extremely toxic \\
\hline A. caroliniana & 0.02 & 0.02 & 0.03 & Extremely toxic \\
\hline \multicolumn{5}{|c|}{ Copper oxychloride $\left(\mathrm{CuCl}_{2} \cdot \mathrm{Cu}(\mathrm{OH})_{2}\right)$} \\
\hline H. eques & 3.15 & 5.14 & 8.38 & Moderately toxic \\
\hline P. canaliculata & 0.91 & 1.35 & 2.01 & Moderately toxic \\
\hline L. minor & 0.01 & 0.01 & 0.02 & Extremely toxic \\
\hline A. caroliniana & 0.02 & 0.02 & 0.03 & Extremely toxic \\
\hline \multicolumn{5}{|c|}{ Copper hydroxide $\left(\mathrm{Cu}(\mathrm{OH})_{2}\right)$} \\
\hline H. eques & 6.65 & 11.36 & 19.40 & Low toxicity \\
\hline P. canaliculata & 0.25 & 0.44 & 0.77 & Highlyt oxic \\
\hline L. minor & - & $<0.01$ & - & Extremely toxic \\
\hline A. caroliniana & - & $>100$ & - & Practically non-toxic \\
\hline \multicolumn{5}{|c|}{ Diquat $+0.1 \%$ Copper oxychloride $\left(\mathrm{D}+0.1 \% \mathrm{CuCl}_{2} .3 \mathrm{Cu}(\mathrm{OH})_{2}\right)$} \\
\hline H. eques & 4.09 & 4.85 & 5.75 & Moderately toxic \\
\hline P. canaliculata & 0.63 & 1.07 & 1.82 & Moderately toxic \\
\hline L. minor & - & $<0.01$ & - & Extremely toxic \\
\hline A. caroliniana & 0.03 & 0.04 & 0.04 & Extremely toxic \\
\hline \multicolumn{5}{|c|}{ Diquat $+0.1 \%$ Copper hydroxide $\left(\mathrm{D}+0.1 \% \mathrm{Cu}(\mathrm{OH})_{2}\right)$} \\
\hline H. eques & 13.91 & 18.97 & 25.87 & Low toxicity \\
\hline P. canaliculata & 0.20 & 0.33 & 0.54 & Highly toxic \\
\hline L. minor & - & $<0.01$ & - & Extremely toxic \\
\hline A. caroliniana & 0.02 & 0.03 & 0.06 & Extremely toxic \\
\hline
\end{tabular}

${ }^{*}$ L.L.: lower limit inferior; ${ }^{* *}$ U.L.: Upper limit; ${ }^{* * *}$ LC: lethal concentration. 
the following organisms: Ctenopharyngodon idella (LC50;96 $\left.\mathrm{h}=53.0 \mathrm{mg} \mathrm{L}{ }^{-1}\right) ;{ }^{[38]}$ Leporinus macrocephalus (LC50;96 $\left.\mathrm{h}=34.76 \mathrm{mg} \mathrm{L}{ }^{-1}\right) ;{ }^{[39]}$ Oreochromis niloticus $\left(\mathrm{LC} 50 ; 96 \mathrm{~h}=37.28 \mathrm{mg} \mathrm{L}^{-1}\right)^{[40]}$ and Phalloceros caudimaculatus (LC50;96 h $\left.=7.17 \mathrm{mg} \mathrm{L}^{-1}\right) .{ }^{[3]}$ Diquat toxicity was similar to Rodeo's, which is practically non toxic for $P$. caudimaculatus $\left(\mathrm{LC} 50 ; 96 \mathrm{~h} \mathrm{>} 975 \mathrm{mg} \mathrm{L}^{-1}\right){ }^{[41]}$

The most sensitive organism to Copper oxychloride was $L$. minor (LC50;7 $\mathrm{d}=0.01 \mathrm{mg} \mathrm{L}^{-1} ; 0.02-0.01 \mathrm{mg} \mathrm{L}^{-1}$ ), and the less sensitive organism was $H$. eques (LC50;48 h $=5.14 \mathrm{mg}$ $\left.\mathrm{L}^{-1} ; 8.38-3.15 \mathrm{mg} \mathrm{L}^{-1}\right)$. The sensitivity sequence of the organisms to $\mathrm{CuCl}_{2} \cdot 3 \mathrm{Cu}(\mathrm{OH})_{2}$ was as follows: L. minor $>$ A. caroliniana $>$ P. canaliculata $>H$. eques (Table 1 ). The most sensitive organism to copper hydroxide was L. minor (LC50;7 d < $\left.0.01 \mathrm{mg} \mathrm{L}^{-1}\right)$, and the less sensitive organism was A. caroliniana (LC50>100 mg L ${ }^{-1}$ ). The sensitivity sequence of the organisms to $\mathrm{Cu}(\mathrm{OH})_{2}$ was the following: $L$. minor $>$ P. canaliculata $>$ H. eques $>$ A. caroliniana (Table 1$)$.

The copper sources in this research were more toxic to $L$. minor than the isolated copper, ${ }^{[42]}$ which caused lethality at concentrations higher than $10 \mathrm{mg} \mathrm{L}^{-1} \cdot \mathrm{Cu}(\mathrm{OH})_{2}$ was more toxic than $\mathrm{CuCl}_{2} \cdot 3 \mathrm{Cu}(\mathrm{OH})_{2}$ to $P$. canaliculata. According to Piyatiratitivorakul et al., ${ }^{[43]}$ copper oxychloride was less toxic than copper oxide to the same snail species (LC50;48 $\mathrm{h}=0.47 \mathrm{mg} \mathrm{L}^{-1}$ ). Copper oxychloride toxicity in $P$. canaliculata was similar to the toxicity observed in Biomphalaria glabrata (LC50;48 $\mathrm{h}=$ $\left.1.43 \mathrm{mg} \mathrm{L}^{-1}\right){ }^{[4]}$ However, it was less toxic than copper sulfate to the same species $\left(\mathrm{LC} 50 ; 96 \mathrm{~h}=0.07 \mathrm{mgL}^{-1}\right) .{ }^{[4]}$

$\mathrm{CuCl}_{2} \cdot 3 \mathrm{Cu}(\mathrm{OH})_{2}$ was more toxic to $H$. eques than to the red tilapia Oreochromis sp. $\left(\mathrm{LC} 50 ; 96 \mathrm{~h}=129.21 \mathrm{mg} \mathrm{L}^{-1}\right),{ }^{[45]}$ but less toxic to Brachydanio rerio (LC50;96 h $\left.=0.1 \mathrm{mg} \mathrm{L}^{-1}\right){ }^{[46]}$ $\mathrm{CuCl}_{2} \cdot 3 \mathrm{Cu}(\mathrm{OH})_{2}$ and $\mathrm{Cu}(\mathrm{OH})_{2}$ were less toxic than copper sulfate to Labeo rohita (LC50;96 $\left.\mathrm{h}=3.15 \mathrm{mg} \mathrm{L}^{-1}\right) ;{ }^{[47]} \mathrm{P}$. caudimaculatus $\left(\mathrm{LC} 50 ; 96 \mathrm{~h}=0.05 \mathrm{mg} \mathrm{L}^{-1}\right)$, B. rerio $(\mathrm{LC} 50 ; 96 \mathrm{~h}=$ $\left.0.13 \mathrm{mg} \mathrm{L}^{-1}\right)$ and $H$. eques (LC50;96 $\left.\mathrm{h}=0.16 \mathrm{mg} \mathrm{L}^{-1}\right) .{ }^{[19]}$

The association $\mathrm{D}+0.1 \% \mathrm{CuCl}_{2} \cdot 3 \mathrm{Cu}(\mathrm{OH})_{2}$ was more toxic to L. minor (LC50;7 $\mathrm{d}<0.01 \mathrm{mg} \mathrm{L}^{-1}$ ) and less toxic to $H$. eques (LC50;48 $\mathrm{h}=18.97 \mathrm{mg} \mathrm{L}^{-1} ; 25.87-13.91 \mathrm{mg} \mathrm{L}^{-1}$ ). The bioindicators sensitivity to this association was as follows: $L$. minor $>$ A. caroliniana $>P$. canaliculata $>H$. eques (Table 1 ). The associations $\mathrm{D}+0.1 \% \mathrm{CuCl}_{2} \cdot 3 \mathrm{Cu}(\mathrm{OH})_{2}$ and $\mathrm{D}+0.1 \mathrm{Cu}(\mathrm{OH})_{2}$ were extremely toxic to the macrophyte, similar to the mixture of $50 \%$ atrazine $+35 \%$ isoproturon in L. minor (EC50;21 d $=$ $0.07 \mathrm{mg} \mathrm{L}^{-1}$ ) and Azolla filiculoides (EC50;21 d $=0.03 \mathrm{mg}$ $\left.\mathrm{L}^{-1}\right){ }^{[48]}$ The associations $\mathrm{D}+0.1 \% \mathrm{CuCl}_{2} \cdot 3 \mathrm{Cu}(\mathrm{OH})_{2}$ and $\mathrm{D}+0.1 \% \mathrm{Cu}(\mathrm{OH})_{2}$ presented moderate and low toxicity to $H$. eques, which was different from the association of glyphosate and a surfactant composed by an alcohol phenol condensed with ethylene oxide and organic sulfonates. These associations were classified as practically non-toxic (LC50;96 h > $975 \mathrm{mg}$ $\mathrm{L}^{-1}$ ) to the fish $P$. caudimaculatus. ${ }^{[41]}$

No variations occurred in temperature, dissolved oxygen and water $\mathrm{pH}$. However, the electrical conductivity has varied. Diquat increased the electrical conductivity in the $H$. eques assay, which ranged from $371.80 \mu \mathrm{S} \mathrm{cm}^{-1}$ in the untreated control to $564.47 \mu \mathrm{S} \mathrm{cm}^{-1}$ at $134.63 \mathrm{mg} \mathrm{L}^{-1}$.

Copper oxichloride and copper hydroxide have also increased the electrical conductivity, from $186.60 \mu \mathrm{S} \mathrm{cm}^{-1}$ and $192.70 \mu \mathrm{S} \mathrm{cm}^{-1}$ (respectively) in the untreated control to
$192.75 \mu \mathrm{S} \mathrm{cm}^{-1}$ and $200.35 \mu \mathrm{S} \mathrm{cm}^{-1}$ at $11.80 \mathrm{mg} \mathrm{L}^{-1}$, in the $P$. canaliculata test; the electrical conductivity increase promoted by $\mathrm{D}+0.1 \% \mathrm{CuCl}_{2} \cdot 3 \mathrm{Cu}(\mathrm{OH})_{2}$ ranged from $361.40 \mu \mathrm{S} \mathrm{cm}^{-1}$ to $415.15 \mu \mathrm{S} \mathrm{cm}^{-1}$ in the $H$. eques test; $\mathrm{D}+0.1 \% \mathrm{Cu}(\mathrm{OH})_{2}$ electrical conductivity ranged from $292.50 \mu \mathrm{S} \mathrm{cm} \mathrm{cm}^{-1}$ to $382.18 \mu \mathrm{S}$ $\mathrm{cm}^{-1}$ in the $H$. eques test and from $193.00 \mu \mathrm{S} \mathrm{cm} \mathrm{cm}^{-1}$ to $200.94 \mu \mathrm{S} \mathrm{cm}^{-1}$ in P. canaliculata. The electrical conductivity increase in the ecotoxicity tests occurs due to the chemicals dissociation, leading to a higher disponibility of the dissoved ions and may interfere in oxygen assimilation, homeostasis and osmotic regulation in fish. ${ }^{[49]}$

\section{Conclusion}

The copper oxychloride and copper hydroxide were effective in the control of unicellular algae $A$. gracilis at rates as high as $0.1 \mathrm{mg} \mathrm{L}^{-1}$, while diquat was effective at $0.8 \mathrm{mg} \mathrm{L}^{-1}$. The associations diquat $+0.1 \%$ copper hydroxide and diquat $+0.1 \%$ copper hydroxide were effective in A. gracilis control at rates as high as 0.2 and $0.4 \mathrm{mg} \mathrm{L}^{-1}$, respectively. Diquat and the copper sources presented no efficacy in $P$. kewesis control. The floating macrophyte $L$. minor was the most sensitive organism to the tested chemicals, and may be used as a bioindicator for environmental monitoring. The chemical products application promoted the increase in water electrical conductivity.

\section{References}

[1] Souza, J.S.; Pedrosa, P.; Gatts, P.V.; Amaral Gravina, G. Aplicação das concentrações e proporções de nutrientes no diagnóstico da eutrofização. Vértices. 2014, 16(1), 203-222.

[2] Moura, D.D.; Fermino, F.S. Aspectos da qualidade da água para abastecimento público na represa Paulo de Paiva Castro sistema cantareira São Paulo-SP. Rev. Metrop. Sust. 2014, 4(2), 96-109.

[3] Henares, M.N.P.; Rezende, F.R.L.; Gomes, G.R.; Cruz, C.; Pitelli, R.A. Eficácia do diquat no controle de Hydrilla verticillata, Egeria densa e Egeria najas e toxicidade para o Guaru (Phallocerus caudimaculatus), em condições de laboratório. Planta Daninha. 2011, 29(2), 279-285.

[4] Oliveira-Filho, E.C.; Lopes, R.M.; Paumgartten, F.J.R. Comparative study on the susceptibility of freshwater species to copper-based pesticides. Chemosphere. 2004, 56(4), 369-374.

[5] Peterson, H.G.; Boutin, C.; Freemark, K.E.; Martin, P.A. Toxicity of hexazinone and diquat to green algae, diatoms, cyanobacteria and duckweed. Aquat. Toxicol. 1997, 39(2), 111-134.

[6] Geoffroy, L.; Teisseire, H.; Couderchet, M.; Vernet, G. 2002. Effect of oxyfluorfen and diuron alone and in mixture on antioxidative enzymes of Scenedesmus obliquus. Pestic. Biochem. Physiol. 2002, $72,178-185$.

[7] Sáenz, M.E.; Alberdi, J.L.; Di Marzio, W.D.; Accorinti, J.; Tortorelli, M.C. Paraquat toxicity to different green algae. Bull. Environ. Contam. Toxicol. 1997, 58(6), 922-928.

[8] Ma, J.; Liang, W. 2001. Acute toxicity of 12 herbicides to the green algae Chlorella pyrenoidosa and Scenedesmus obliquus. Bull. Environ. Contam. Toxicol. 2001, 67, 347-351.

[9] Schamphelaere, K.C.; Stauber, J.L.; Wilde, K.L.; Scott, J.M.; Brown, P.; Franklin, N.; Creighton, N.M.; Janssen, C. Toward a biotic ligand model for freshwater green algae: Surface-bound and internal copper are better predictors of toxicity than free $\mathrm{Cu} 2+$-ion activity when $\mathrm{ph}$ is varied. Environ. Sci. Technol. 2005, 39, 2067-2072.

[10] Einicker-Lamas, M.; Antunes M.G.; Benavides Fernandes, T.; Silva, F. L.S.; Guerra, F.; Miranda, K.; Attias, M.; Oliveira, M.M. 2002. Euglena gracilis as a model for study of $\mathrm{Cu} 2 \mathrm{P}$ and $\mathrm{Zn} 2 \mathrm{P}$ toxicity and accumulation in eukaryotic cells. Environ. Pollut. 2002, 120, 779-786.

[11] Rodrigues, L.H.R.; Arenzon, A.; Raya-Rodriguez, M.T.; Fontoura, N. F. Avaliação da sensibilidade de Raphidocelis subcapitata 
(Chlorococcales, Chlorophyta) ao sulfato de cobre e sulfato de zinco através de ensaios de toxicidade crônica. Biociências. 2003, 11(2), 137-144.

[12] Sant'Anna, C.L.; Azevedo, M.T.P. Uma ameaça à qualidadeda água. Espalhadas pelo Brasil. Pesqu. Fapesp. 2000, 53, 28-30.

[13] Zhang, W.; Tan, N.G. J.; Li, S.F.Y. NMR-based metabolomics and LC-MS/MS quantification reveal metal-specific tolerance and redox homeostasis in Chlorella vulgaris. Mol. BioSyst. 2014, 10, 149-160.

[14] Hook, S.E.; Osborn, H.L.; Gissi, F.; Moncuquet, P.; Twine, N.A.; Wilkins, M.R.; Adams, M.S. RNA-Seq analysis o the toxicant-induced transcriptom e of the marine diatom, Ceratoneis closterium. Mar. Genomics. 2014, 16, 45-53.

[15] Kumar, K.S., Dahms, H.U., Lee, J.S., Kim, H.C., Lee, W.C., Shin, K.H. Algal photosynthetic responses to toxic metals and herbicides assessed by chlorophyll a fluorescence. Ecotoxicol. Environ. Safety. 2014, 104, 51-71.

[16] Masser, M.P.; Murphy, T.R.; Shelton, J.L. Aquatic weed management: herbicides; Masser, M.P.; Murphy, T.R.; Shelton, J.L. Southern Regional Aquaculture Center Puplication. 2001, 361.

[17] Martins, D.; Trigueiro, L.R.C.; Domingos, V.D.; Terra, M.A.; Costa, N.V. Sensitivity of different accesses of Egeria najas and Egeria densa to the herbicides diquat and fluridone. Planta Daninha. 2007, 25(2), 351-358.

[18] Costa, C.R.; Olivi, P.; Botta, C.M.; Espindola, E.L. A toxicidade em ambientes aquáticos: discussão e métodos de avaliação. Quím. Nova. 2008, 31(7), 1820-1830.

[19] Silva, A.F.; Cruz, C.; Rezende, F.R.L.; Yamauchi, A.K.F.; Pitelli, R.A. Copper sulfate acute ecotoxicity and environmental risk for tropical fish. Acta Scient. Biol. Sci. 2014, 36(4), 377-381.

[20] Florêncio, T.; Carraschi, S.P.; Cruz, C.; Silva, A.F.; Marques, A.M.; Pitelli, R.A. Bioindicadores neotropicais de ecotoxicidade e risco ambiental de fármacos de interesse para aquicultura. Bol. Inst. Pesca. 2014, 40(4), 569-576.

[21] Kielak, E.; Sempruch, C.; Mioduszewska, H.; Klocek, J.; Leszczyński, B. Phytotoxicity of Roundup Ultra 360 SL in aquatic ecosystems: Biochemical evaluation with duckweed (Lemna minor L.) as a model plant. Pestic. Biochem. Physiol. 2011, 99(3), 237-243.

[22] Silva, A.F.; Cruz, C.; Neto, A.N.; Pitelli, R.A. Ecotoxicity of herbicides for the aquatic macrophyte (Azolla caroliniana). Planta Daninha. 2012, 30(3), 541-546.

[23] Companhia Estadual de Tecnologia de Saneamento Ambiental (CETESB). Norma Técnica L5.306. Determinação de pigmentos fotossintetizantes- clorofila- $A, B$ e $C$ e feofitina-A: método de ensaio. CETESB: São Paulo, Brazil, 1990; 22p.

[24] Hamilton, M.A.; Russo, R.C.; Trurston, R.V. Trimmed Spearman Karber: methods for estimating median lethal concentrations in toxicity bioassays. Environ. Sci. Technol. 1977, 11, 714-719.

[25] Zucker, E. Hazard evaluation division standard evaluation procedure: acute toxicity test for freshwater fish. U.S. Environmental Protection Agency, Office of Pesticide Programs, EPA 540-9-85-006; EPA: Washington, DC, 1985.

[26] Sipaúba-Tavares, L.H.; Ibarra, L.C.C.; Fioresi, T.B. Cultivo de Ankistrodesmus gracilis (Reisch) KORSIKOV (Chlorophyta) em laboratório utilizando meio CHU12 e de macrófita com NPK. Bol. Inst. Pesca. 2009, 35, 111-118.

[27] Associação Brasileira de Normas Técnicas (ABNT) NBR 15088: Ecotoxicologia aquática - Toxidade aguda-Método de ensaio com peixes. ABNT, Brazil, 2011; 19p.

[28] Organization for Economic Cooperation and Development (OECD). Lemna sp. growth inhibition test. In GUIDELINE for testing of chemicals. OECD: Paris, 2002; 22 p.

[29] Wong, P.K.; Chang, L. Effects of copper, chromium and nickel on growth, photosynthesis and chlorophyll a synthesis of Chlorella pyrenoidosa 251. Environ. Poll. 1991, 72(2), 127-139.

[30] Barón, M.; Arellano, J.B.; Gorgé, J.L. Copper and photosystem II: a controversial relationship. Physiol. Plant. 1995, 94(1), 174-180.
[31] Pogson, B.J.; Niyogi, K.K.; Björkman, O.; DellaPenna, D. Altered xanthophyll composition adversely affect chlorophyll accumulation and non-photochemical quenching in Arabidopsis mutant. Proc. Nat. Acad. Sci. 1998, 95, 13324-13329.

[32] Fairchild, J.F.; Ruessler, D.S.; Haverland, P.S.; Carlson, A.R. Comparative sensitivity of Selenastrum capricornutum and Lemna minor to sixteen herbicides. Environ. Contam. Toxicol. 1997, 32(4), 353-357.

[33] Ma, J.; Xu, L.; Wang, S.; Zheng, R.; Jin, S.; Huang, S.; Huang, Y. Toxicity of 40 herbicides to the green alga Chlorella vulgaris. Ecotoxicol. Environ. Safety, 2002, 51(2), 128-132.

[34] Ma, J.; Wang, S.; Wang, P.; Ma, L.; Chen, X.; Xu, R. Toxicity assessment of 40 herbicides to the green alga Raphidocelis subcapitata. Ecotoxicol. Environ. Safety. 2006, 63(3), 456-462.

[35] FAO/WHO. Pesticide residues in food - 1994. Evaluations - 1994. Part I Residues, Vol. 1. Rome, Food and Agriculture Organization of the United Nations, Joint FAO/WHO Meeting on Pesticide Residues (FAO Plant Production and Protection Paper 131/1), 1995.

[36] Durborow, R.M.; Tucker, C.S.; Gomelsky, B.I.; Onders, R.J.; Mims, S.D. Aquatic weed control in ponds; Durborow, R.M.; Tucker, C.S.; Gomelsky, B.I.; Onders, R.J.; Mims, S.D. Kentucky State University Aquaculture Program, a KSU Land Grant Program, 2008; $24 \mathrm{p}$.

[37] Melo, L.E.L.; Coler, R.A.; Watanabe, T.; Batalla, J.F. Developing the gastropod Pomacea lineata (Spix, 1827) as a toxicity test organism. Hydrobiologia. 2000, 429(1-3), 73-78.

[38] El-Deen, M.A.S.; Rogers, W.A. Acute toxicity and some hematological changes in grass carp exposed to diquat. J. Aquat. Animal Health. 1992, 4(4), 277-280.

[39] Henares, M.N.P.; Cruz, C.; Gomes, G.R.; Pitelli, R.A.; Machado, M.R. F. Toxicidade aguda e efeitos histopatológicos do Diquate na brânquia e no fígado do piauçu (Leporinus macrocephalus). Pesticidas: r. ecotoxicol. e meio ambiente. 2007, 17, 107-116.

[40] Henares, M.N.P.; Cruz, C.; Gomes, G.R.; Pitelli, R.A.; Machado, M.R. F. Toxicidade aguda e efeitos histopatológicos do herbicida diquat na brânquia e no fígado da tilápia nilótica (Oreochromis niloticus). Acta Scient. Biol. Sci. 2008, 30(1), 77-82.

[41] Shiogiri, N.S., Carraschi, S.P., Cubo, P., Schiavetti, B.L., Cruz, C., Pitelli, R.A. Ecotoxicity of glyphosate and aterbane ${ }^{\circ}$ br surfactant on guaru (Phalloceros caudimaculatus). Acta Scient. Biol. Sci. 2010, 32 (3), 285-289.

[42] Proença, M.A.; Oliveira, L.L.D.D.; Rocha, O. Efeito tóxico do cobre sobre o crescimento da macrófita aquática Lemna minor. Per. Eletr. Fórum Amb. A. Paulista. 2012, 8(12), 196-207.

[43] Piyatiratitivorakul, P.; Ruangareerat, S.; Vajarasathira, B.Comparative toxicity of heavy metal compounds to the juvenile golden apple snail, Pomacea sp. Fres. Environ. Bull. 2006, 15(5), 379-384.

[44] Venturini, F.P., Cruz, C., Pitelli, R.A. Toxicidade aguda do sulfato de cobre e do extrato aquoso de folhas secas de nim para o caramujo (Pomacea canaliculata). Acta Scien. Biol. Sci. 2008, 30(2), 179-184.

[45] Boock, M.V.; Machado Neto, J.G. Estudos toxicológicos do oxicloreto de cobre para tilápia vermelha (Oreochromis sp.). Arq. Inst. Biol. 2000, 67(2), 215-221.

[46] Boock, M.V.; Machado-Neto, J.G. Estudos sobre a toxicidade aguda do oxicloreto de cobre para o peixe Poecilia reticulata. Bol. Inst. Pesca. 2005, 31(1), 29-35.

[47] Latif, A.; Ali, M.; Sayyed, A.H.; Iqbal, F.; Usman, K.; Rauf, M.; Kaoser, R. Effect of Copper sulphate and lead nitrate, administered alone or in combination, on the histology of liver and kidney of Labeo rohita. Pakistan J. Zool. 2013, 45(4), 913-920.

[48] Coutris, C.; Merlina, G.; Silvestre, J.; Pinelli, E.; Elger, A. Can we predict community-wide effects of herbicides from toxicity tests on macrophyte species?. Aquat. Toxicol. 2011, 101(1), 49-56.

[49] Ikefuti, C.V.; Carraschi, S.P.; Barbuio, R.; Cruz, C.; Pádua, S.B.; Onaka, E.M.; Ranzani-Paiva, M.J.T. Teflubenzuron as a tool for control of trichodinids in freshwater fish: Acute toxicity and in vivo efficacy. Experim. Parasit. 2015, 154, 108-112 